\title{
Bactericidal effect of nisin and reuterin on methicillin-resistant Staphylococcus aureus (MRSA) and S. aureus ATCC 25937
}

\author{
Hany Mohamed YEHIA ${ }^{1 *}$ (D), Afrah Fahad ALKHURIJI², Ioannis SAVVAIDIS ${ }^{3}$, Abdulrahman Hamad Al-MASOUD ${ }^{1}$
}

\begin{abstract}
Nisin and reuterin are used in processed foods as preservatives. They are considered to be potential sources of natural antibiotics for the treatment of food contaminated by antibiotic-resistant bacteria, such as methicillin-resistant Staphylococcus aureus. We try to compare the best effect of both nisin and reuterin on the growth of methicillin-resistant S. aureus (MRSA) and S. aureus ATCC 25923. The results indicated that nisin at different concentrations inhibited the growth of methicillin-resistant $S$. aureus after $4 \mathrm{~h}$, whereas after 12 and $24 \mathrm{~h}$, the bacteria have regrown and reactivated. S. aureus ATCC 25923 was not affected by nisin concentration and has continuously grew at all times. Reuterin at different concentrations gradually inhibited the growth of methicillin-resistant S. aureus and S. aureus ATCC 25923 and declined after $12 \mathrm{~h}$ for both. Therefore, it can be deduced that nisin alone exerts a bacteriostatic effect on methicillin-resistant S. aureus but not on S. aureus ATCC 25923. Reuterin is considered as bactericidal effect on both microorganisms. The combination of nisin at a concentration of 25.6 and reuterin at a concentration of $5.2 \mathrm{mg} / \mathrm{mL}$ exerted a bactericidal effect on both microorganisms. By mixing nisin with reuterin, it can be more active against both microorganisms.
\end{abstract}

Keywords: nisin; reuterin; methicillin-resistant Staphylococcus aureus.

Practical Application: Control of Methicillin-resistant Staphylococcus aureus and Staph. aureus by combination of nisin and reuterin.

\section{Introduction}

In many countries, Staphylococcus aureus is the second or third most common bacterial pathogen following Salmonella and Clostridium perfringens that cause food poisoning (Cosgrove et al., 2003). Methicillin-resistant S. aureus (MRSA) is considered to be among the bacteria distributed and causing infections in the USA and Europe, and this leads to higher risk in public health, higher morbidity and mortality in comparison with non-resistant strains. MRSA infections generate higher expenses in the area of public health and leads to higher morbidity and mortality rates compared with non-resistant strains (Cosgrove et al., 2003). The prevalence of $S$. aureus in raw milk cheese and other different foods are high and noticed as a biofilm formation, thus, the improvements in the hygiene process are strongly recommended (Carvalho et al., 2021). Controlling the growth of both of the microbes is highly challenging for many microbiologists. The use of natural antimicrobial agents enables food preservation without causing changes in tastes and flavors.

Nisin is a polypeptide consisting of 34 amino acids with a molecular mass of 3,510 Da. It is a bacteriocin produced by the Lactococcus lactis subsp. lactis. (dairy starter) bacterium. Nisin structure was solved in 1971, It possesses three unusual amino acids: dehydroalanine, lanthionine, and $\beta$-methyllanthionine (Gross \& Morell, 1971). It is considered to exhibit an antimicrobial activity against other bacteria. Moreover, it has attracted the interest of food microbiologists, bacterial geneticists, and protein engineers in the last decade. Food microbiologists' interest in nisin has been stimulated by the fact that nisin received the status of Generally Recognized as Safe (GRAS) in 1988 (Food and Drug Administration, 1988). Inhibition tests against pathogenic bacteria showed that nisin had a greater effect on Gram positive bacteria, while OVEO had an effect on both Gram positive and Gram negative bacteria (Pabon et al., 2021). Many studies have demonstrated the capacity of nisin to inhibit the microbial growth of gram positive bacteria, including the highly pathogenic bacteria found in food, such as $S$. aureus (Godoy-Santos et al., 2019).

Nisin is a natural peptide, and a broad wide spectrum against Gram-positive bacteria and belonged to class I bacteriocin (Bierman \& Sahl, 1991). However, it exhibits little or no activity against Gram-negative bacteria, yeasts, and molds (Hurst, 1981). For decades, nisin has been used as a natural preservative for food such as cheese, semi-preserved meats, canned goods, and chocolate milk to control the growth of S. aureus (DelvesBroughton, 1990; Felicio et al., 2015). Recently, nisin has been applied as a biopreservative and has been demonstrated to work synergistically with some drugs to control the growth of MRSA 
as biofilm as well as other pathogens (Brumfitt et al., 2002; Dosler \& Gerceker, 2011; Field et al., 2015; Shin et al, 2015).

Researchers thought that nisin exerts an effect on lipid II, which was the precursor of peptidoglycan of cell wall of bacteria (Breukink et al., 1999; Breukink \& Kruijff, 2006). Other authors have explained that nisin strongly decreased the membrane potential of cells as judged by the distribution of the lipophilic tetraphenylphosphonium cation (Ruhr \& Sahl, 1985; Wiedemann et al., 2001). The morphologies of some bacteria were changed by nisin due to membrane permeabilization, as happened in Bacillus (Hyde et al., 2006). The formation of nisinlipid II aggregates in Bacillus subtilis led to membrane disruption and cell death (Scherer et al., 2015). Others suggested that the cell death was caused by nisin-lipid but driven by a membrane defect caused by alternative mechanisms (Prince et al., 2016). Hence, the downstream effects of nisin binding to lipid II which caused the cell death appear to be complex. Notably, lipid II is the target of novel antibiotics, such as daptomycin and teixobactin, and for these compounds, the killing mechanism is not entirely understood (Müller et al., 2016; Öster et al., 2018).

Jensen et al. (2020), discussed the ability of nisin to control the growth of MRSA strains and then compared the nisin minimum inhibitory concentrations (MIC) of 18 S. aureus strains representing both the methicillin-sensitive S. aureus (MSSA) and MRSA isolates. They observed a slight difference in nisin MICs for MSSA and MRSA strains, suggesting that the SSCmec resistance determinant harbored by MRSA strains does not change susceptibility to nisin.

When CA-MRSA cells exposed of to nisin resulted in rapid killing after 4 hours and the MRSA strain was capable of regrowth. To elucidate the rapid killing of MRSA by nisin, they adopted superresolution structured-illumination microscopy (SR-SIM) and transmission electron microscopy (TEM) to investigate the morphological changes by adding nisin in a CA-MRSA USA300 model strain. Interestingly, the exposure of the MRSA cells to nisin for $30 \mathrm{~min}$ resulted in distinct morphological changes, including cell shrinkage, DNA condensation, and cell lysis.

Some authors suggested that whether the nisin activity against bacterial cells is bacteridal or bacteriostatic, this limits factor due to the condition of tests (Delves-Broughton et al., 1996). If the bacterial cell is active, the bactericidal effect of nisin will have, whether if the cell not active (due to medium or temperature of food not optimum, $\mathrm{pH}$, water activity or/and nutrition availability), the bacteriostatic effect of nisin rather than bactericidal (Sahl, 1991; Maisnier-Patin et al., 1992). This is of course the basis of food preservation and is used in the multifactorial preservation of food known to food microbiologists as the "hurdle technology" (Leistner \& Gorris, 1994).

Some strains of Lactobacillus reuteri produced reuterin ( $\beta$-hydroxypropionaldehyde) under anaerobic condition from the fermentation of glycerol (Axelsson et al., 1989). Reuterin is water soluble, active at a wide range of $\mathrm{pH}$ values, and resistant to proteolytic and lipolytic enzymes (El-Ziney et al.,1999). El-Ziney \& Debevere (1998) reported the bactericidal effect of reuterin on both L. monocytogenes and Escherichia coli O157:H7 in milk and cottage cheese.
The bacteriostatic activity of reuterin $(8 \mathrm{AU} / \mathrm{mL})$ against Listeria monocytogenes in milk and its bactericidal activity against S. aureus and E. coli $\mathrm{O} 157 \mathrm{H7}$, Salmonella choleraesuis ssp., Yersinia enterocolitica, Aeromonas hydrophila ssp., and Campylobacter jejuni were studied by Arqués et al. (2004). Other studies have considered reuterin as an antimicrobial agent (Axelsson et al., 1989; Chung et al., 1989; Rasch, 2002; Cleusix et al., 2007; Spinler et al., 2008; Garde et al., 2014).

This study aimed to evaluate the antimicrobial activity of nisin, reuterin, or combination of both as a natural biopreservative against MRSA and S. aureus ATCC 25923. Changes in the cell wall have been observed through the growth in the liquid culture medium.

\section{Materials and methods}

\subsection{Bacterial strains}

MRSA strain was obtained from the Laboratory of Food Microbiology, College of Food and Agriculture, King Saud University, and Staphylococcus aureus ATCC 25923 through this study.

\subsection{Time-kill curves}

According to the method by Jensen et al. (2020) with little modification, MRSA and S. aureus ATCC 25923 were grown overnight at $37^{\circ} \mathrm{C}$ in Brain Heart Infusion Broth (BHI) (Oxoid, $\mathrm{CM} 1136)$ and diluted in physiological saline $(0.9 \% \mathrm{NaCl})$ to reach the $0.5 \mathrm{McFarland}$ turbidity as previously described.

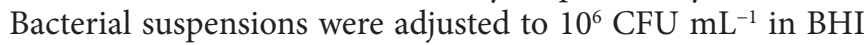
containing $0,3.2,6.4,12.8$, or $25.6 \mathrm{mg} \mathrm{mL}^{-1}$ of pure nisin at a final volume of $100 \mathrm{~mL}$ and then incubated with aeration $(150 \mathrm{rpm})$ at $37^{\circ} \mathrm{C}$. Cell counts were determined via tenfold serial dilution on BHI agar (Oxoid, CM357) every hour for the first $4 \mathrm{~h}$ and then after 12 and $24 \mathrm{~h}$. Experiments were conducted in duplicate. The determination of the MIC of overnight cultures was performed for one of the duplicate experiments to determine susceptibility after prolonged exposure. The suspension of both

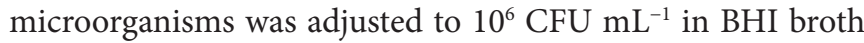
containing reuterin at concentrations of $0,0.625,0.125,2.5$, and $5 \mathrm{mg} \mathrm{mL}^{-1}$.

\subsection{Minimum inhibitory concentration assay}

Nisin A was purchased from Sigma-Aldrich (N5764). According to the method by Jensen et al. (2020), a fresh stock solution of nisin in $\mathrm{HCl}(0.02 \mathrm{M})$ was prepared before each experiment with a final concentration of $102.4 \mu \mathrm{g} \mathrm{mL}^{-1}$ and then diluted twofold to 51.2, 22.6, 12.8, 6.4, 3.2, 1.6, and $0.8 \mu \mathrm{gL}^{-1}$. The MIC for the different concentrations of nisin was determined in a 96-well format. Overnight cultures of MRSA and S. aureus ATCC 25923 were diluted in BHI (Oxoid, CM1135) broth to reach the $0.5 \mathrm{McF}$ arland turbidity (corresponding to $\sim 10^{8} \mathrm{CFU}$ $\mathrm{mL}^{-1}$ ). The bacterial suspensions were adjusted to $5 \times 10^{5} \mathrm{CFU}$ $\mathrm{mL}^{-1}$ in Mueller-Hinton (MH) broth (Oxoid, CM0405) in wells containing standard twofold dilutions of nisin in a final volume of $100 \mu \mathrm{L}$. The plates were incubated for $18-24 \mathrm{~h}$ with shaking $(300 \mathrm{rpm})$ at $37^{\circ} \mathrm{C}$. All experiments were conducted in triplicate. 
MIC was defined as the concentration of nisin at which growth was inhibited at $600 \mathrm{~nm}$.

Reuterin was produced previously in our laboratory from $L$. reuteri DSMZ in de Man, Rogosa, and Sharpe (MRS) broth (Oxoid, $\mathrm{CM} 0361)$ and stored in refrigerator at $4{ }^{\circ} \mathrm{C}$ until use. Reuterin was prepared also in $\mathrm{HCl}(0.02 \mathrm{M})$, with a final concentration of $10 \mu \mathrm{g} \mathrm{mL}^{-1}$, and then diluted twofold to $5.2,2.6,1.3,0.65$, $0.325,0.1625$, and $0.08125 \mu \mathrm{g} \mathrm{mL} \mathrm{m}^{-1}$. MIC was determined as previously mentioned for nisin in a 96 -well format.

\subsection{Combined effect of nisin and reuterin against $S$. aureus (MRSA) and S. aureus ATCC 25923}

Based on the MIC, we used nisin and reuterin at concentrations of 25.6 and $5.2 \mu \mathrm{g} \mathrm{mL}^{-1}$, respectively, in the BHI broth to study the effect on MRSA and S. aureus ATCC 25923 in duplicate experiments conducted and on different time intervals. In each experiment, either MRSA or S. aureus ATCC 25923 was inoculated at approximately $10^{6} \mathrm{cfu} / \mathrm{mL}$ into screw-capped flasks containing $200 \mathrm{~mL}$ BHI broth, incubated at $37^{\circ} \mathrm{C}$, and shaken at $150 \mathrm{rpm}$. Each culture ( $1 \mathrm{~mL}$ each) was withdrawn every $1 \mathrm{~h}$ (for the first $4 \mathrm{~h}$ ) to determine the total viable count using the pour plate method on $\mathrm{BHI}$ agar and incubated at $37^{\circ} \mathrm{C}$ for $24 \mathrm{~h}$ and following the identification of the total viable count after 12 and $24 \mathrm{~h}$ of incubation period.

\subsection{Minimum Bactericidal Concentrations (MBC)}

The MBC of the of nisin and/or reuterin or in combination were carried out on Methicilline resistant S. aureus (MRSA) and $S$. aureus ATCC 25923 in comparison with the positive control of each microbe. For this purpose, $10 \mu \mathrm{l}$ of the corresponding inhibitory concentration and the immediately higher concentrations $(\mathrm{MIC} \times 2$ and $\mathrm{MIC} \times 4)$ were subcultured on petri dishes containing Mueller-Hinton agar (Oxoid, CM0337). After 24h of incubation period, the MBC was determined and defined as the lowest concentration that inhibited visible growth of the subculture.

\subsection{Microscopic examination of cells during the growth on nisin-reuterin combination medium}

Cells of MRSA and S. aureus ATCC 25923 were withdrawn every hour for the first $4 \mathrm{~h}$ and then after 12 and $24 \mathrm{~h}$ of growth and stained with Gram stain to show the changes in the cells caused by nisin and reuterin.

\section{Results and discussion}

\subsection{Effect of nisin on the viability of methicillin-resistant S. aureus and S. aureus ATCC 25937}

Figure 1 presents the time-kill curve to evaluate the viability of MRSA were in media contained nisin at different concentrations for 1-24 h. For all the tested concentrations of nisin $\left(3.2-25.6 \mu \mathrm{g} \mathrm{mL}^{-1}\right)$, the viable count decreased during the first $4 \mathrm{~h}$ in a time- and concentration-dependent manner. This indicates that until the first $4 \mathrm{~h}$, the growth was totally inhibited and the bacteria have regrown after and increased until the growth period ended $(24 \mathrm{~h})$. Mutant of nisin resistant strain of
MRSA may be exhibited during exposure in medium contained nisin and regrowth again after or $>4 \mathrm{~h}$. The authors explained that if the bacteria regrowth phenotypic in the cultures medium contained nisin (Jensen et al. (2020)). They also suggested that the ability of $S$. aureus to resume growth after $4 \mathrm{~h}$ of nisin exposure does not seem to be caused by stable mutations. Viable count of 20 strains of MRSA strain were reduced its growth after $2 \mathrm{~h}$ of the experiment while the initial killing, 11 of the MRSA strains were capable of regrowth while remaining fully sensitive to nisin (Brumfitt et al., 2002). Oliveira et al., (2020), studied the effect of different nisin concentration on the resistant $S$. aureus isolate (L47) and found that the population in Baird parker agar was reduced to at least $5 \log 10 \mathrm{CFU} / \mathrm{mL}$ (without causing total inhibition) from the positive control value was selected for the following tests.

Contrarily, the lag phase of S. aureus ATCC 25923 was extended to about $5 \mathrm{~h}$ but was continued all over the time of the incubation period and reached to maximum viable counts during the $24 \mathrm{~h}$. This means that S. aureus ATTC 25923 was resistant to nisin (Figure 2).

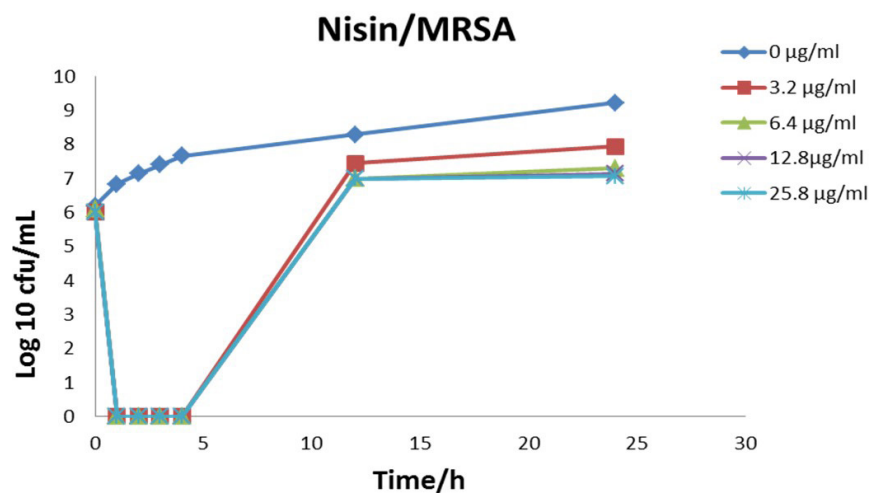

Figure 1. Effect of nisin on the time-kill curves of MRSA. Overnight cultures of methicillin-resistant $S$. aureus (MRSA) adjusted to $\sim 10^{6} \mathrm{CFU} \mathrm{mL} \mathrm{m}^{-1}$ were grown in $\mathrm{BHI}$ broth at different nisin concentrations

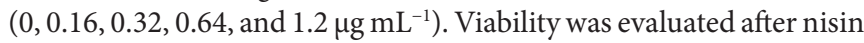
exposure by determining CFU mL $\mathrm{mL}^{-1}$ every hour for the first $0-4 \mathrm{~h}$ and then after 12 and $24 \mathrm{~h}$.

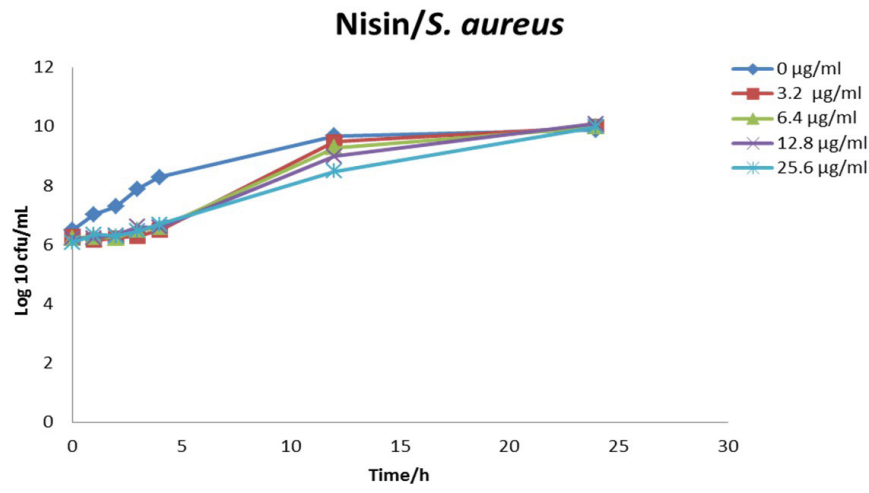

Figure 2. Effect of nisin on the time-kill curves of $S$. aureus ATCC 25937. Overnight cultures of S. aureus ATCC 25923 adjusted to $\sim 10^{6} \mathrm{CFU} \mathrm{mL} \mathrm{m}^{-1}$ were grown in $\mathrm{BHI}$ broth at different concentrations $\left(0,0.16,0.32,0.64\right.$, and $1.2 \mu \mathrm{g} \mathrm{mL} \mathrm{L}^{-1}$ nisin $)$. Viability was evaluated after nisin exposure by determining CFU mL $^{-1}$ every hour for the first $0-4 \mathrm{~h}$ and then after 12 and $24 \mathrm{~h}$. 


\subsection{Minimum inhibitory concentrations of nisin and reuterin for methicillin resistant $S$. aureus (MRSA) and S. aureus ATCC 25937}

The MICs of nisin for MRSA and S. aureus ATCC 25937 are presented in Table 1. In the broth dilution assays, MRSA and S. aureus ATCC 25937 exhibited nisin MICs of 51.2-102.4 $\mu \mathrm{g}$ $\mathrm{mL}^{-1}$. Contrarily, the MICs of reuterin for MRSA and S. aureus ATCC 25937 were 5.2 and $0.65-5.2 \mu \mathrm{g} \mathrm{mL}^{-1}$ ).

Hampikyan (2009) [35], has been inoculated sucuk doughs with $S$. aureus and treated by nisin, its counts were ranging from 6.15 to $6.49 \log \mathrm{CFU} / \mathrm{g}$ (for control and nisin treated respectively), yielded statistically similar (P 0.05). The S. aureus count increased to 7.10-7.65 log CFU/g for sucuk containing 25-100 g/g for nisin and the control, respectively, at the end of the fermentation period (5 days). Conversely, for sucuk dough containing 150 and $200 \mathrm{~g} / \mathrm{g}$ nisin, the count decreased to 5.81-4.51 log CFU/g, respectively. At nisin concentrations of 150 and $200 \mathrm{~g} / \mathrm{g}$, no S. aureus was observed after 35 and 30 days, respectively. However, the $S$. aureus count on day 45 in sucuk containing 0 to $100 \mathrm{~g} / \mathrm{g}$ ranged from 3.54 to $5.68 \mathrm{log} \mathrm{CFU} / \mathrm{g}$.

The effect of nisin depends on the concentration and amount of nisin as well as the bacterial contamination level in foods. Nisin works in a concentration-dependent manner in terms of the amount applied and the level of bacterial contamination of the food. Porretta et al. (1966), explained that in canned pea containing 810 spores B. stearothermophilus spores needed twice much than contained 141 spores to achieve the same preserved effect.

The growth condition transcribes if the effect of nisin on vegetative cells is either bactericidal or bacteriostatic (DelvesBroughton et al., 1996). If the bacterial cells are in an energized state, its bactericidal effect will have and in non-energize cell (the cells are under non-optimized conditions as $\mathrm{pH}$, temperature, water activity, and nutrient availability), the effect of nisin will be bacteriostatic rather than bactericidal (Sahl, 1991; MaisnierPatin et al., 1992). Food microbiologists called the basis of food preservation that is also used in multifactorial preservation as the "hurdle technology" (Leistner, 1994a). Nisin has the ability to inhibit the growth of Gram-positive spore-forming bacteria, such as Bacillus and Clostridium spp. The activity of nisin against spores is predominantly sporostatic rather than sporicidal (Egan et al., 2016). Bacillus spp. that their spores rupture mechanically its coat is more sensitive to nisin than do by lysis (Gould \& Hurst, 1962). Moreover, they explained that spores damaged by heat are more sensitive to nisin lysis. For example, Clostridium sporogenes PA 3679 treated with heat for $3 \mathrm{~min}$ at $121 \mathrm{C}$ was 10 times more heat-sensitive than those that have not been heat treated. Jarvis (1967), also observed that both the vegetative cells and spores of B. stearothermophilus and Clostridium thermosaccharolyticum are remarkably sensitive to nisin compared with mesophilic spore-forming bacteria. Another interesting observation is that both the spores and vegetative cells of the thermophilic spore-formers B. stearothermophilus and $C$. thermosaccharolyticum are remarkably sensitive to nisin compared with mesophilic spore-formers (Jarvis, 1967).

\subsection{Effect of reuterin on the viability of methicillin-resistant S. aureus and S. aureus ATCC 25937}

The effect of reuterin on MRSA is clearly described in Figure 3. From the figure, it can be seen that the concentrations of 5.2 and $2.6 \mu \mathrm{g} / \mathrm{mL}^{-1}$ completely inhibited bacterial growth in the liquid medium after $12 \mathrm{~h}$ of incubation period. Reuterin concentrations of 1.3 and $0.65 \mu \mathrm{g} / \mathrm{mL}^{-1}$ enabled the growth to quickly reach the steady state and continuous the without increasing or reducing. Thus, we concluded that reuterin is more effective on MRSA than nisin and completely inhibited bacterial growth. By this, we can say that reuterin exerts a bactericidal effect whereas nisin a bacteriostatic effect on MRSA. Reuterin-

Table 1. The MICs of nisin for methicillin resistant S. aureus (MRSA) and S. aureus strains.

\begin{tabular}{|c|c|c|c|c|}
\hline & $\mathrm{MIC}$ of nisin $\mu \mathrm{g} \mathrm{mL}^{-1}$ & $\begin{array}{l}\text { Growth at optical density } \\
600 \mathrm{~nm}\end{array}$ & MIC of reuterin $\mu \mathrm{g} \mathrm{mL} L^{-}$ & $\begin{array}{l}\text { Growth at optimal density } \\
600 \mathrm{~nm}\end{array}$ \\
\hline \multirow[t]{8}{*}{ MRSA } & 102.4 & $\mathrm{NG}$ & 5.2 & NG \\
\hline & 51.2 & NG & 2.6 & 1.241 \\
\hline & 25.6 & 0.936 & 1.3 & 1.368 \\
\hline & 12.8 & 1.401 & 0.65 & 1.484 \\
\hline & 6.4 & 1.679 & 0.32 & 1.666 \\
\hline & 3.2 & 1.911 & 0.16 & 1.787 \\
\hline & 1.6 & 1.984 & 0.08 & 1.88 \\
\hline & 0.8 & 1.999 & 0.04 & 2.0 \\
\hline \multirow[t]{9}{*}{ S. aureus ATCC 25923} & MIC of nisin $\mu \mathrm{g} \mathrm{mL^{- }}$ & $\begin{array}{l}\text { Growth at optimal density } \\
600 \mathrm{~nm}\end{array}$ & MIC of reuterin $\mu \mathrm{g} \mathrm{mL}^{-}$ & $\begin{array}{l}\text { Growth at optimal density } \\
600 \mathrm{~nm}\end{array}$ \\
\hline & 102.4 & NG & 5.2 & NG \\
\hline & 51.2 & NG & 2.6 & NG \\
\hline & 25.6 & 1.27 & 1.3 & NG \\
\hline & 12.8 & 1.547 & 0.65 & NG \\
\hline & 6.4 & 1.738 & 0.32 & 1.101 \\
\hline & 3.2 & 1.925 & 0.16 & 1.20 \\
\hline & 1.6 & 2.126 & 0.08 & 1.52 \\
\hline & 0.8 & 2.20 & 0.04 & 1.66 \\
\hline
\end{tabular}


producing positive strain $L$. reuteri SD2112 was capable of $86 \%$ inhibition, but Bifidobacterium lactis Bb-12 demonstrated no capability for inhibition (Lahtinen et al., 2007).

The effect of reuterin on S. aureus ATCC 25937 is clearly demonstrated in Figure 4. It can be seen from the figure that at concentrations of $0.65-5.2 \mu \mathrm{g} / \mathrm{mL}^{-1}$, bacterial growth in liquid medium was inhibited after $12 \mathrm{~h}$ of incubation period. It can be deduced that reuterin is more effective than nisin, which appeared no inhibition against $S$. aureus. We also concluded that reuterin exerts a bacteriostatic effect whereas nisin a bactericidal effect on S. aureus ATCC 25937. Arqués et al. (2004) mentioned that nisin effect as a bactericidal against $S$. aureus in milk at $37^{\circ} \mathrm{C}$, over $4 \mathrm{~h}$, while the growth was resumed again after that and reaching counts similar to those in control milk after $24 \mathrm{~h}$. Rodriguez et al. (2001), revealed that when a nisin producing starter was added to cheese made from raw milk, a slight inhibitory effect of the bacteriocin on S. aureus was observed. Contrarily, when nisin was

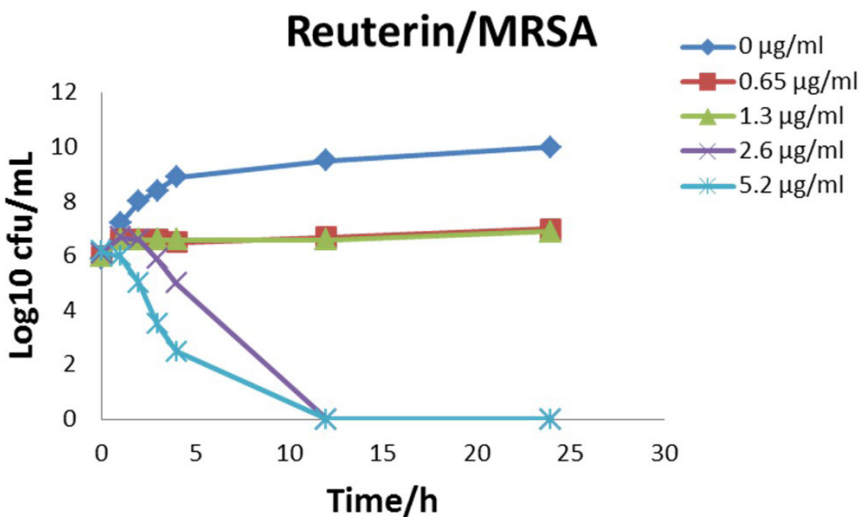

Figure 3. Effect of reuterin on the time-kill curves of MRSA. Overnight cultures of MRSA adjusted to $\sim 10^{6} \mathrm{CFU} \mathrm{mL} \mathrm{m}^{-1}$ were grown in BHI broth at different reuterin concentrations $\left(0,0.64,1.3,2.6\right.$, and $\left.5.2 \mu \mathrm{g} \mathrm{mL} \mathrm{m}^{-1}\right)$. Viability was assessed after reuterin exposure by determining CFU mL $\mathrm{m}^{-1}$ every hour for the first $0-4 \mathrm{~h}$ and then after 12 and $24 \mathrm{~h}$.

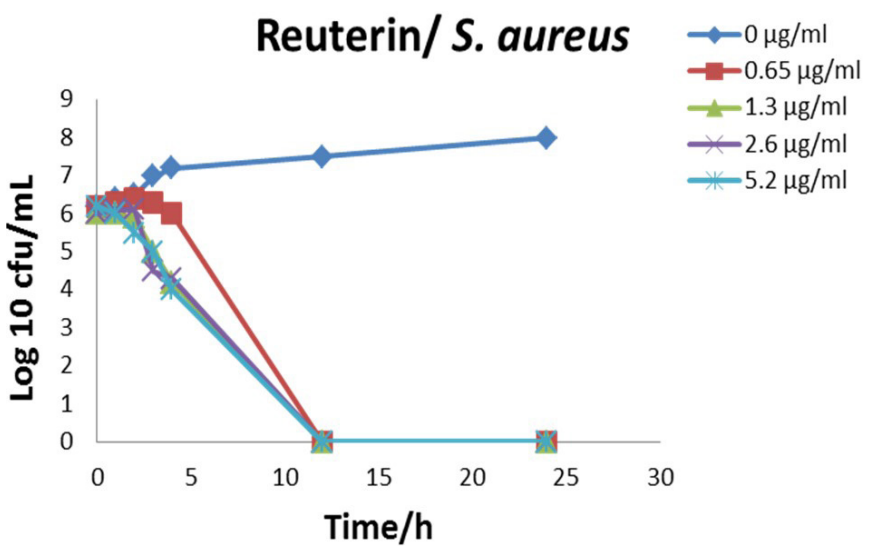

Figure 4. Effect of reuterin on the time-kill curves of $S$. aureus ATCC 25937. Overnight cultures of $S$. aureus ATCC 25937adjusted to $\sim 10^{6} \mathrm{CFU} \mathrm{mL} \mathrm{mL}^{-1}$ were grown in $\mathrm{BHI}$ broth at different reuterin concentrations $\left(0,0.64,1.3,2.6\right.$, and $\left.5.2 \mu \mathrm{g} \mathrm{mL}^{-1}\right)$. Viability was assessed after reuterin exposure by determining the $\mathrm{CFU} \mathrm{mL} \mathrm{mL}^{-1}$ every hour for the first $0-4 \mathrm{~h}$ and then after 12 and $24 \mathrm{~h}$. added to white pickled cheese, inhibition of bacterial pathogen was not noted (Abdalla et al., 1993). This finding agrees with our data regarding the effect of nisin on pathogenic $S$. aureus ATCC 25937 as explained above.

\subsection{Effect of nisin and reuterin combination on the viability of methicillin-resistant S. aureus and S. aureus ATCC 25937}

The combination of nisin and reuterin at concentrations of 25.6-5.2 $\mu \mathrm{g} \mathrm{mL}^{-1}$ improved the ability to control the growth of both MRSA and S. aureus ATCC 25937 and extended its effect for more than $24 \mathrm{~h}$ (Figures 5 and 6). This combination may change the permeability of the outer membrane for both bacteria and cause a lethal effect against both microorganisms. The authors suggested that the combination of bacteriocin and other preservation mechanisms leads to the elimination of resistant to bacteriocins in target strains and/or extend its inhibitory activity against Gram-negative species (Stevens et al., 1991). We can have added that this effect carried out against Gram-positive bacteria as described in our study.

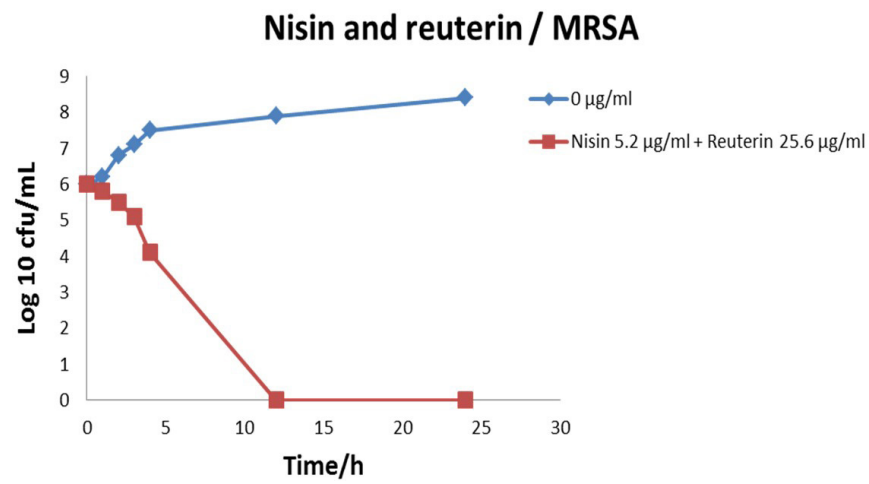

Figure 5. Effect of nisin and reuterin on the time-kill curves of MRSA. Overnight cultures of MRSA adjusted to $\sim 10^{6} \mathrm{CFU} \mathrm{mL} \mathrm{m}^{-1}$ were grown in $\mathrm{BHI}$ broth supplemented with nisin and reuterin at 25.6 and $5.2 \mu \mathrm{g} \mathrm{mL} \mathrm{L}^{-1}$, respectively. Viability as $\mathrm{CFU} \mathrm{mL} \mathrm{m}^{-1}$ was assessed for the first $0-4 \mathrm{~h}$ and then after 12 and $24 \mathrm{~h}$.

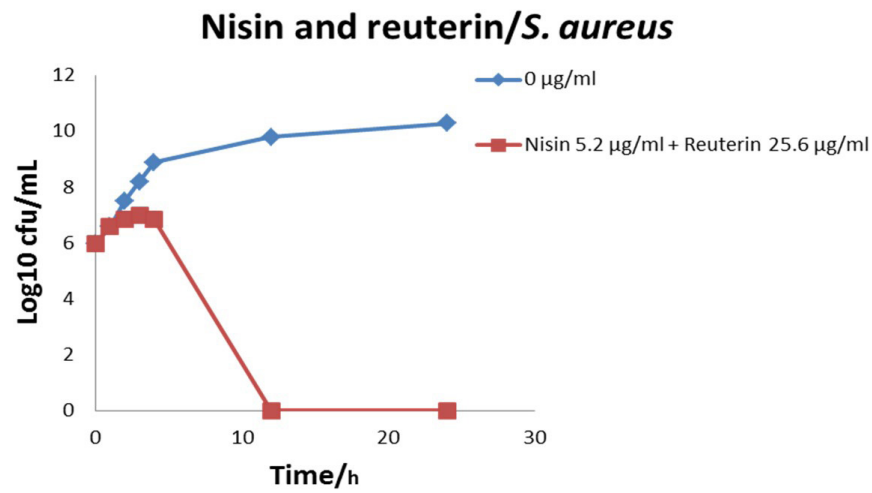

Figure 6. Effect of nisin and reuterin on the time-kill curves of S. aureus ATCC 25937. Overnight cultures of S. aureus ATCC 25937 adjusted to $\sim 10^{6} \mathrm{CFU} \mathrm{mL} \mathrm{mL}^{-1}$ were grown in $\mathrm{BHI}$ broth supplemented with nisin

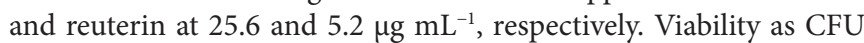
$\mathrm{mL}^{-1}$ was assessed for the first $0-4 \mathrm{~h}$ and then 12 and $24 \mathrm{~h}$. 
The combination effect, which is called a synergistic effect, of nisin with other antimicrobials on Gram-positive bacteria has been described by Mansour et al. (1998) and Boussouel et al., (2000) in milk. The combination of reuterin and other antimicrobials was discussed in a few studies, such as that of Arqués et. al. (2008) [45] who confirmed that the synergistic effect between reuterin and nisin on the inhibition of $L$. monocytogenes in milk has been achieved. El-Ziney \& Debevere (1998), observed that the activity of reuterin against $L$. monocytogenes was enhanced with $3 \%$ salt and that the synergistic effect was dependent on salt concentration. The synergistic effect of reuterin in combination with lactic acid during meat decontamination has also been reported (El-Ziney et al.,1999).

Arqués et al., (2008), reported that a synergistic antimicrobial effect on $S$. aureus was detected when nisin was combined with reuterin and the lactoperoxidase system (LPS), resulting in counts $5 \log \mathrm{cfu} / \mathrm{mL}$ lower than in control cuajada after $12 \mathrm{~d}$ at $10{ }^{\circ} \mathrm{C}$. The treatment combining these 3 natural biopreservatives at low concentrations, within the hurdle concept of food preservation, might be a useful tool to control the growth of pathogens such as L. monocytogenes and S. aureus, which might have access to milk used for the manufacture of dairy products through post pasteurization contamination.

\subsection{Minimum inhibitory concentration (MIC) and minimum bactericidal concentration (MBC) of methicillin-resistant S. aureus and S. aureus ATCC 25937}

Data in Table 2 shows the zone of inhibition of nisin against MRSA strain was $15 \mathrm{~mm}$ in diameter, while was $10 \mathrm{~mm}$ against S. aureus ATCC 25937, while of reuterin was 20 and $18 \mathrm{~mm}$ in diameter against both respectively. Minimum inhibitory concentration (MIC) and of nisin against MRSA and S. aureus ATCC 25937 was $51.2 \mathrm{mg} / \mathrm{mL}$ for both microbe, while reuterin was 5.2 and $0.65 \mathrm{mg} / \mathrm{mL}$, respectively. Minimum bactericidal concentration (MBC) of nisin was 5 and $10 \mathrm{mg} / \mathrm{mL}$ and against MRSA and S. aureus was 5 and $10 \mathrm{mg} / \mathrm{mL}$, respectively. While $\mathrm{MBC}$ for reuterin were 5 and $5 \mathrm{mg} / \mathrm{mL}$ against MRSA and $S$. aureus ATCC 25937, respectively.

So reuterin is considered to be a bactericide effect against both microorganisms, while nisin was bacteriostatic against MRSA alone and no effect against S. aureus ATCC 25937.

\subsection{Microscopic examination of cells during the growth on nisin-reuterin combination medium}

As examined the cells by compound microscope after stained with Gram stain in the absence of nisin and reuterin combination revealed that both MRSA and S. aureus ATCC 25937 are a Gram-positive, spherical assemble in clusters the membrane is regular (Data not add). After $1 \mathrm{~h}$ of growth in the presence of nisin and reuterin at concentrations of 25.6 and $5.2 \mu \mathrm{g} \mathrm{mL} \mathrm{m}^{-1}$, the cells started to change, and some of the cell walls begin to appear to damage and this structure of clusters not all compact state in comparison with normal cells. By increasing the time exposure to nisin and reuterin, the damages worsened, and the membrane lost its integrity until the structures exhibited an irregular shape at the end of the 24-h period. Many of the cells appeared as ghost cells when the cells were lysed after exposure to nisin and reuterin.

Jensen et al. (2020), exposed S. aureus to nisin and noticed striking differences, bulging, and invaginations in the cell membrane. They suggested that nisin caused membrane damage that resulted in the disposure of unstructured membranous material at the septal site. Interestingly, the DNA in cells exposed to nisin appeared condensed and fragmented, and the chromosomal DNA structure was altered. This was considered to be an indirect mechanism. Also explained by electron microscope that nisin led to splitting of $S$. aureus daughter, while the cells untreated by nisin appeared showed the staining pattern that characterizes daughter cells having separated. Also, the cells exposed to nisin are smaller than the untreated ones.

The cell induced by nisin $\left(6.4 \mu \mathrm{g} \mathrm{mL}^{-1}\right)$ which was examined via electron microscopy indicated that the cells profound alterations in the DNA structure as condensed electron light regions and fragmented DNA that were clearly visible only in cells exposed to nisin. In untreated cells, the DNA is not clearly distinguishable in the cytoplasm (Jensen et al., 2020).

A rapid lysis in the cells (about 14\%) exposed to nisin and that appeared as ghost cells was also found via transmission electron microscopy (Jensen et al., 2020).

The partial depolarization of $S$. aureus cytoplasmic membranes was caused by nisin (Chung \& Hancock, 2000). The mode of action of nisin considered the cytoplasmic membrane as the biological target. The membranes were disrupted by nisin and by pore formation, membrane insertion, and simultaneous

Table 2. Zone of inhibition (mm), minimum inhibitory concentration (MIC) and minimum bactericidal concentration (MBC) of nisin and reuterin on MRSA and S. aureus ATCC 25937.

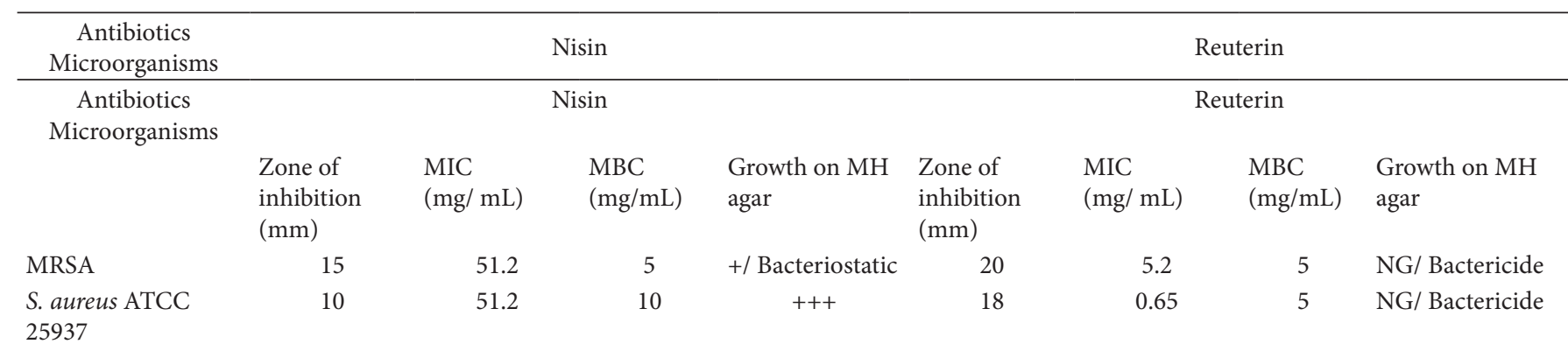

+: Growth; NG: no growth; -: no effect. 
depolarization. The increase in membrane permeability disturbs membrane transport and inhibits energy production as well as the biosynthesis of proteins and nucleic acids (Bruno et al., 1992; Breukink et al., 1998; Raju et al., 2003). S. aureus was completely inhibited by nisin $(100 \mathrm{IU} / \mathrm{mL})$ in broth system (Masschalck et al., 2001). Scannell et al., (1997), stated that nisin (500 IU/g) effectively prevented the growth of $S$. aureus under similar conditions. Proton motive was disrupted by pore formation through nisin and $\mathrm{pH}$ equilibrium lead to leakage of ions and hydrolysis of ATP and cells were death (Arauz et al., 2009).

Vollenweider \& Lacroix (2004) reported that reuterin can also enhance membrane permeability, facilitate antimicrobial action, and inhibit the ribonucleotide reductase and thioredoxin activities and thereby DNA synthesis. The combination of nisin and LPS exerted a higher synergistic antimicrobial effect on L. monocytogenes at higher temperatures and persisted at refrigerator temperatures. It is also important to note that the application of nisin, reuterin, and LPS in combination achieved the greatest rate of inactivation on the two pathogens tested, achieving reductions to levels well below those considered to be harmful for consumers, even under refrigeration conditions of temperature abuse.

Some other researchers were used chitosan coating and $M$. aquatica L. essence against $E$. coli, S. aureus and L. monocytogenes and its capability as a natural, healthy and safe preservative system to improve Iranian white cheese shelf-life and noticed significant growth inhibition of $88.54 \%$ and $85.9 \%$ were obtained for $S$. aureus (Zavareh \& Ardestani (2020). Combination of nisin an natamycin were applied to foods as used in lemon soft drinks to inhibit the growth of L. plantarum and Z. bailii cultures and remained stable after 120 days (Garavaglia et al., 2019).

\section{Conclusion}

A synergistic bactericidal activity of nisin in combination with reuterin against methicillin-resistant S. aureus (MRSA) and $S$. aureus ATCC 25937 and transformed the effect from bacteriostatic to bactericides according to the destruction of cell membrane as demonstrated by microscopic examination and extension effect on the cell viability for more than $24 \mathrm{~h}$.

\section{Conflict of interest}

The authors declare that there are no competing interests associated with the manuscript.

\section{Availability of data and material}

The datasets used and/or analyzed during the current study are available from the corresponding author on reasonable request.

\section{Funding}

Researchers Supporting Project number (RSP-2021/97), King Saud University, Riyadh, Saudi Arabia.

\section{Author contributions}

H.M.Y. and A.B.A. contributed to study design. A.F.A. and I.N.S contributed to data acquisition. H.M.Y organized the database, performed the statistical analysis, and wrote the first manuscript. All authors revised, improved, read, and approved the final manuscript. All authors have read and agreed to the published version of the manuscript.

\section{Acknowledgement}

Researchers Supporting Project number (RSP-2021/97), King Saud University, Riyadh, Saudi Arabia.

\section{References}

Abdalla, O. M., Davidson, P. M., \& Christen, G. L. (1993). Survival of selected pathogenic bacteria in white pickled cheese made with lactic acid bacteria or antimicrobials. Journal of Food Protection, 56(11), 972-976. http://dx.doi.org/10.4315/0362-028X-56.11.972. PMid:31113078.

Arauz, L. J., Jozala, A. F., Mazzola, P. G., \& Vessoni Penna, T. C. (2009). Nisin biotechnological production and application: a review. Trends in Food Science \& Technology, 20(3-4), 146-154. http://dx.doi. org/10.1016/j.tifs.2009.01.056.

Arqués, J. L., Fernández, J., Gaya, P., Nuñez, M., Rodríguez, E., \& Medina, M. (2004). Antimicrobial activity of reuterin in combination with nisin against food-borne pathogens. International Journal of Food Microbiology, 95(2), 225-229. http://dx.doi.org/10.1016/j. ijfoodmicro.2004.03.009. PMid:15282134.

Arqués, J. L., Rodrıguez, E., Nuñez, M., \& Medina, M. (2008). Antimicrobial activity of nisin, reuterin, and the lactoperoxidase system on Listeria monocytogenes and Staphylococcus aureus in Cuajada, a semisolid dairy product manufactured in Spain. Journal of Dairy Science, 91(1), 70-75. http://dx.doi.org/10.3168/jds.2007-0133. PMid:18096926.

Axelsson, L. T., Chung, T. C., Dobrogosz, W. J., \& Lindgren, S. E. (1989). Production of a broad spectrum antimicrobial substance by Lactobacillus reuteri. Microbial Ecology in Health and Disease, 2(2), 131-136. http://dx.doi.org/10.3109/08910608909140210.

Bierman, G., \& Sahl, H. G. (1991). Induction of autolysis of Staphylococcus simulans 22 by peps and nisin and influence of the cationic peptides on the activity of the autolytic enzymes. In G. Jung \& H.G. Sahl (Eds.), Nisin and novel lantibiotics (pp. 386-396). Leiden: Escom.

Boussouel, N., Mathieu, F., Revol-Junelles, A. M., \& Millière, J. B. (2000). Effects of combinations of lactoperoxidase system and nisin on the behaviour of Listeria monocytogenes ATCC 15313 in skim milk. International Journal of Food Microbiology, 61(2-3), 169-175. http://dx.doi.org/10.1016/S0168-1605(00)00365-2. PMid:11078167.

Breukink, E., \& de Kruijff, B. (2006). Lipid II as target for antibiotics. Nature Reviews. Drug Discovery, 5(4), 321-332. http://dx.doi. org/10.1038/nrd2004. PMid:16531990.

Breukink, E., Van Kraaij, C., Van Dalen, A., Demel, R. A., Siezen, R. J., Kruijff, B., \& Kuipers, O. P. (1998). The orienta-tion of nisin in membranes. Biochemistry, 37(22), 8153-8162. http://dx.doi. org/10.1021/bi9727971. PMid:9609711.

Breukink, E., Wiedemann, I., Van Kraaij, C., Kuipers, O. P., Sahl, H. G., \& Kruijff, B. (1999). Use of the cell wall precursor lipid II by a pore-forming peptide antibiotic. Science, 286(5448), 2361-2364. http://dx.doi.org/10.1126/science.286.5448.2361. PMid:10600751.

Brumfitt, W., Salton, M. R., \& Hamilton-Miller, J. M. (2002). Nisin, alone and combined with peptidoglycan-modulating antibiotics: activity against methicillin-resistant Staphylococcus aureus and vancomycin-resistant enterococci. The Journal of Antimicrobial Chemotherapy, 50(5), 731-734. http://dx.doi.org/10.1093/jac/dkf190. PMid:12407132. 
Bruno, M. E. C., Kaiser, R., \& Montville, A. T. J. (1992). Depletion of proton motive force by nisin in Listeria monocytogenes cells. Applied and Environmental Microbiology, 58(7), 2255-2259. http://dx.doi. org/10.1128/aem.58.7.2255-2259.1992. PMid:1637163.

Carvalho, L. G., Alvim, M. M. A., Fabri, R. L., \& Apolonio, A. C. M. (2021). Staphylococcus aureus biofilm formation in Minas Frescal cheese packaging. International Journal of Dairy Technology, 74(3), 575-580. http://dx.doi.org/10.1111/1471-0307.12783.

Chung, T. C., Axelsson, L., Lindgren, S. E., \& Dobrogosz, W. J. (1989). In vitro studies on reuterin synthesis by Lactobacillus reuteri. Microbial Ecology in Health and Disease, 2(2), 137-144. http://dx.doi. org/10.3109/08910608909140211.

Chung, W., \& Hancock, R. E. W. (2000). Action of lysozyme and nisin mixtures against lactic acid bacteria. International Journal of Food Microbiology, 60(1), 25-32. http://dx.doi.org/10.1016/S01681605(00)00330-5. PMid:11014519.

Cleusix, V., Lacroix, C., Vollenweider, S., Duboux, M., \& Le Blay, G. (2007). Inhibitory activity spectrum of reuterin produced by Lactobacillus reuteri against intestinal bacteria. BMC Microbiology, 7(1), 101. http://dx.doi.org/10.1186/1471-2180-7-101. PMid:17997816.

Cosgrove, S. E., Sakoulas, G., Perencevich, E. N., Schwaber, M. J., Karchmer, A. W., \& Carmeli, Y. (2003). Comparison of mortality associated with methicillin resistant and methicillin susceptible Staphylococcus aureus bacteremia: a meta-analysis. Clinical Infectious Diseases, 36(1), 53-59. http://dx.doi.org/10.1086/345476. PMid:12491202.

Delves-Broughton, J. (1990). Nisin and its uses as a food preservative. Food Technology, 44(11), 100-117.

Delves-Broughton, J., Blackburn, P., Evans, R. J., \& Hugenholtz, J. (1996). Applications of the bacteriocin, nisin. Antonie van Leeuwenhoek, 69(2), 193-202. http://dx.doi.org/10.1007/BF00399424. PMid:8775979.

Dosler, S., \& Gerceker, A. A. (2011). In vitro activities of nisin alone or in combination with vancomycin and ciprofloxacin against methicillinresistant and methicillin-susceptible Staphylococcus aureus strains. Chemotherapy, 57(6), 511-516. http://dx.doi.org/10.1159/000335598. PMid:22302084.

Egan, K., Field, D., Rea, M. C., Ross, R. P., Hill, C., \& Cotter, P. D. (2016). Bacteriocins: novel solutions to age old spore-related problems? Frontiers in Microbiology, 7, 461. http://dx.doi.org/10.3389/ fmicb.2016.00461. PMid:27092121.

El-Ziney, M. G., \& Debevere, J. M. (1998). The effect of reuterin on Listeria monocytogenes and Escherichia coli O157:H7 in milk and cottage cheese. Journal of Food Protection, 61(10), 1275-1280. http://dx.doi.org/10.4315/0362-028X-61.10.1275. PMid:9798141.

El-Ziney, M. G., van den Tempel, T., Debevere, J., \& Jakobsen, M. (1999). Application of reuterin produced by Lactobacillus reuteri 12002 for meat decontamination and preservation. Journal of Food Protection, 62(3), 257-261. http://dx.doi.org/10.4315/0362-028X-62.3.257. PMid:10090245.

Felicio, B. A., Pinto, M. S., Oliveira, F. S., Lempk, M. W., Pires, A. C., \& Lelis, C. A. (2015). Effects of nisin on Staphylococcus aureus count and physicochemical properties of Minas Frescal cheese. Journal of Dairy Science, 98(7), 4364-4369. http://dx.doi.org/10.3168/jds.20159520. PMid:25981063.

Field, D., Cotter, P. D., Ross, R. P., \& Hill, C. (2015). Bioengineering of the model antibiotic nisin. Bioengineered, 6(4), 187-192. http:// dx.doi.org/10.1080/21655979.2015.1049781. PMid:25970137.

Food and Drug Administration - FDA. (1988). Nisin preparation: affirmation of GRAS status as a direct human food ingredient (Vol. 53). USA: FDA.
Garavaglia, J., Pinto, L. M. N., Souza, D., Castilhos, J., Rossi, R. C., Machado, I. C. K., Ramos, R. C. S., \& Ziegler, D. D. R. (2019). Natamycin and nisin to improve shelf life and minimize benzene generation in lemon soft drinks. Food Science and Technology, 39(2), 274-279. http://dx.doi.org/10.1590/fst.13217.

Garde, S., Gómez-Torres, N., Hernández, M., \& Ávila, M. (2014). Susceptibility of Clostridium perfringens to antimicrobials produced by lactic acid bacteria: reuterin and nisin. Food Control, 44, 22-25. http://dx.doi.org/10.1016/j.foodcont.2014.03.034.

Godoy-Santos, F., Pitts, B., Stewart, P. S., \& Mantovani, H. C. (2019). Nisin penetration and efficacy against Staphylococcus aureus biofilms under continuous-flow conditions. Microbiology, 165(7), 761-771. http://dx.doi.org/10.1099/mic.0.000804. PMid:31088602.

Gould, G. W., \& Hurst, A. (1962). Inhibition of Bacillus spore development by nisin and subtilin. In 8th International Congress of Microbiology (Vol. 2, pp. 18). Montreal. Abstract.

Gross, E., \& Morell, J. L. (1971). The structure of nisin. Journal of the American Chemical Society, 93(18), 4634-4635. http://dx.doi. org/10.1021/ja00747a073. PMid:5131162.

Hampikyan, H. (2009). Efficacy of nisin against Staphylococcus aureus in experimentally contaminated sucuk, a Turkish-type fermented sausage. Journal of Food Protection, 72(8), 1739-1743. http://dx.doi. org/10.4315/0362-028X-72.8.1739. PMid:19722412.

Hurst, A. (1981). Nisin. Advances in Applied Microbiology, 27, 85-123. http://dx.doi.org/10.1016/S0065-2164(08)70342-3.

Hyde, A. J., Parisot, J., Mcnichol, A., \& Bonev, B. B. (2006). Nisininduced changes in Bacillus morphology suggest a paradigm of Antibiotic Action. Proceedings of the National Academy of Sciences of the United States of America, 103(52), 19896-19901. http://dx.doi. org/10.1073/pnas.0608373104. PMid:17179039.

Jarvis, B. (1967). Resistance to nisin and production of nisin-inactivating enzyme by several Bacillus species. Journal of General Microbiology, 47(1), 33-48. http://dx.doi.org/10.1099/00221287-47-1-33. PMid:4962191.

Jensen, C., Li, H., Vestergaard, M., Dalsgaard, A., Frees, D., \& Leisner, J. J. (2020). Nisin damages the septal membrane and triggers DNA condensation in methicillin-resistant Staphylococcus aureus. Frontiers in Microbiology, 11, 1007. http://dx.doi.org/10.3389/fmicb.2020.01007. PMid:32582052.

Lahtinen, S. J., Jalonen, L., Ouwehand, A. C., \& Salminen, S. J. (2007). Specific Bifidobacterium strains isolated from elderly subjects inhibit growth of Staphylococcus aureus. International Journal of Food Microbiology, 117(1), 125-128. http://dx.doi.org/10.1016/j. ijfoodmicro.2007.02.023. PMid:17462772.

Leistner, L. (1994a). Further developments in the utilization of hurdle technology for food preservation. Journal of Food Engineering, 22(1-4), 421-432. http://dx.doi.org/10.1016/0260-8774(94)90044-2.

Leistner, L., \& Gorris, L. G. M. (1994). Food preservation by combined processes: final report: FLAIR concerted action (no. 7, Subgroup B) (EUR 15776 EN, European Commission Directorate General XII). Brussels: CEC.

Maisnier-Patin, S., Deschamps, N., Tatini, S. R., \& Richard, J. (1992). Inhibition of Listeria monocytogenes in Camembert cheese made with a nisin-producing starter. Le Lait, 72(3), 249-263. http://dx.doi. org/10.1051/lait:1992318.

Mansour, M., Linder, M., Millière, J. B., \& Lefebvre, G. (1998). Combined effect of Nisin, lactic acid and potassium sorbate on Bacillus licheniformis spores in milk. Le Lait, 78(1), 117-128. http://dx.doi. org/10.1051/lait:1998115.

Masschalck, B., Van Houdt, R., \& Michiels, C. W. (2001). High pressure increases bactericidal activity and spectrum of lactoferrin, lacto- 
ferricin and nisin. International Journal of Food Microbiology, 64(3), 325-332. http://dx.doi.org/10.1016/S0168-1605(00)00485-2. PMid:11294354.

Müller, A., Wenzel, M., Strahl, H., Grein, F., Saaki, T. N. V., Kohl, B., Siersma, T., Bandow, J. E., Sahl, H. G., Schneider, T., \& Hamoen, L. W. (2016). Daptomycin inhibits cell envelope synthesis by interfering with fluid membrane microdomains. Proceedings of the National Academy of Sciences of the United States of America, 113(45), E7077-E7086. http://dx.doi.org/10.1073/pnas.1611173113. PMid:27791134.

Oliveira, A. P. D., Costa, M. M., Nogueira, D. M., \& Silvadias, F. (2020). Characterisation of Staphylococcus aureus strains from milk and goat cheese and evaluation of their inhibition by gallic acid, nisin and velame of the Brazilian caatinga. International Journal of Dairy Technology, 73(2), 345-356. http://dx.doi.org/10.1111/1471-0307.12673.

Öster, C., Walkowiak, G. P., Hughes, D. E., Spoering, A. L., Peoples, A. J., Catherwood, A. C., Tod, J. A., Lloyd, A. J., Herrmann, T., Lewis, K., Dowson, C. G., \& Lewandowski, J. R. (2018). Structural studies suggest aggregation as one of the modes of action for teixobactin. Chemical Science, 9(47), 8850-8859. http://dx.doi.org/10.1039/ C8SC03655A. PMid:30627403.

Pabon, K. S. M., Aponte, A. A. A., Duque, J. F. S., \& Villada, H. S. (2021). Characterization and antimicrobial efficacy of active biocomposite containing polylactic acid, oregano essential oil and nisin for pork storage. Food Science and Technology. Ahead of Print. http://dx.doi. org/10.1590/fst.67420.

Porretta, A., Giannone, L., \& Casolari, A. (1966). Impiego della nisina nella lavorazione dei piselIi. Industria Conserve, 2, 89-91.

Prince, A., Sandhu, P., Ror, P., Dash, E., Sharma, S., Arakha, M., Jha, S., Akhter, Y., \& Saleem, M. (2016). Lipid-II independent antimicrobial mechanism of nisin depends on its crowding and degree of oligomerization. Scientific Reports, 6(1), 37908. http:// dx.doi.org/10.1038/srep37908. PMid:27897200.

Raju, C. V., Shamasundar, B. A., \& Udupa, K. S. (2003). The use of nisin as a preservative in fish sausage stored at ambient and refrigerated temperatures. International Journal of Food Science \& Technology, 38(2), 171-185. http://dx.doi.org/10.1046/j.1365-2621.2003.00663.x.

Rasch, M. (2002). The influence of temperature, salt and $\mathrm{pH}$ on the inhibitory effect of reuterin on Escherichia coli. International Journal of Food Microbiology, 72(3), 225-231. http://dx.doi.org/10.1016/ S0168-1605(01)00637-7. PMid:11845821.

Rodriguez, E., Arques, J. L., Gaya, P., Tomillo, J., Nunez, M., \& Medina, M. (2001). Behaviour of Staphylococcus aureus in semi-hard cheeses made from raw milk with nisin producing cultures. Milchwissenschaft. Milk Science International, 55, 633-635.

Ruhr, E., \& Sahl, H. G. (1985). Mode of action of the peptide antibiotic nisin and influence on the membrane potential of whole cells and on cytoplasmic and artificial membrane vesicles. Antimicrobial Agents and Chemotherapy, 27(5), 841-845. http://dx.doi.org/10.1128/ AAC.27.5.841. PMid:4015074.

Sahl, H. G. (1991). Pore formation in bacterial membranes by cationic lantibiotics. In G. Jung \& H.G. Sahl (Eds.), Nisin and novel lantibiotics (p. 347-358). Leiden: Escom.

Scannell, A. G. M., Hill, C., Buckley, D. J., \& Arendt, E. K. (1997). Determination of the influence or organic acids and nisin on shelf-life and microbiological safety aspects of fresh pork sausage. Journal of Applied Microbiology, 83(4), 407-412. http://dx.doi. org/10.1046/j.1365-2672.1997.00248.x. PMid:9351222.

Scherer, K. M., Spille, J. H., Sahl, H. G., Grein, F., \& Kubitscheck, U. (2015). The antibiotic nisin induces lipid II aggregation, causing membrane instability and vesicle budding. Biophysical Journal, 108(5), 1114-1124. http://dx.doi.org/10.1016/j.bpj.2015.01.020. PMid:25762323.

Shin, J. M., Ateia, I., Paulus, J. R., Liu, H., Fenno, J. C., Rickard, A. H., \& Kapila, Y. L. (2015). Antimicrobial nisin acts against saliva derived multi-species biofilms without cytotoxicity to human oral cells. Frontiers in Microbiology, 6, 617. http://dx.doi.org/10.3389/ fmicb.2015.00617. PMid:26150809.

Spinler, J. K., Taweechotipatr, M., Rognerud, C. L., Ou, C. N., Tumwasorn, S., \& Versalovic, J. (2008). Human-derived probiotic Lactobacillus reuteri demonstrate antimicrobial activities targeting diverse enteric bacterial pathogens. Anaerobe, 14(3), 166-171. http://dx.doi. org/10.1016/j.anaerobe.2008.02.001. PMid:18396068.

Stevens, K. A., Sheldon, B. W., Klapes, N. A., \& Klaenhammer, T. R. (1991). Nisin treatment for the inactivation of Salmonella species and other Gram-negative bacteria. Applied and Environmental Microbiology, 57(12), 3613-3615. http://dx.doi.org/10.1128/ aem.57.12.3613-3615.1991. PMid:1785933.

Vollenweider, S., \& Lacroix, C. (2004). 3-Hydroxypropionaldehyde: applications and perspectives of biotechnological production. Applied Microbiology and Biotechnology, 64(1), 16-27. http://dx.doi. org/10.1007/s00253-003-1497-y. PMid:14669058.

Wiedemann, I., Breukink, E., Van Kraaij, C., Kuipers, O. P., Bierbaum, G., De Kruijff, B., \& Sahl, H. G. (2001). Specific binding of nisin to the peptidoglycan precursor lipid II combines pore formation and inhibition of cell wall biosynthesis for potent antibiotic activity. The Journal of Biological Chemistry, 276(3), 1772-1779. http://dx.doi. org/10.1074/jbc.M006770200. PMid:11038353.

Zavareh, S. A. H. T., \& Ardestani, F. (2020). Antibacterial effects of chitosan coating containing Mentha aquatica L. essence against Escherichia coli, Staphylococcus aureus and Listeria monocytogenes in Iranian white cheese. International Journal of Dairy Technology, 73(3), 585-593. http://dx.doi.org/10.1111/1471-0307.12678. 